\title{
ANTECEDENT OF CUSTOMER SATISFACTION WITH IMPACT OF LOGISTICS SERVICE QUALITY, E-PAYMENT THROUGH MODERATING ROLE OF INFORMATION AND COMMUNICATION TECHNOLOGY
}

\author{
Shahzad Ahmad Khan ${ }^{1 *}$, Ammar Husain ${ }^{2}$, Ali Haider ${ }^{3}$, Mubashar Hassan Zia ${ }^{4}$ \\ ${ }^{1 *}$ Department of Management Studies, Bahria University. Islamabad, Pakistan; ${ }^{2}$ Lecturer, Department of Business \\ Management, Karakoram International University Gilgit, Gilgit, Pakistan; ${ }^{3}$ Faculty of Management Science, \\ International Islamic University, Islamabad, Pakistan; ${ }^{4}$ Faculty of Management Science, Riphah International University, \\ Islamabad, Pakistan. \\ Email: ${ }^{1 *}$ sahmad.buic@ bahria.edu.pk, ${ }^{2}$ dr.ammar@kiu.edu.pk, ${ }^{3}$ eelihaider@iiu.edu.pk, ${ }^{4}$ mubashar.hassan@ riphah.edu.pk \\ Article History: Received on $23^{\text {rd }}$ March 2021, Revised on $5^{\text {th }}$ April 2021, Published on $9^{\text {th }}$ April 2021
}

\begin{abstract}
Purpose: Customer Satisfaction is the top priority in all business sectors, so the effect of different variables was evaluated on customer satisfaction which is taken as the dependent. Independent variable is e-Payment, Logistic Service Quality, and e-Traceability. Moderating Role was studied of the Use of ICT (Information and Communication Technology).

Methodology: This research was carried out on the logistic companies of major cities of Pakistan, including Islamabad, Peshawar, Lahore, and Karachi. The data was cross-sectional in nature and with the involvement of different geographical locations, data collection took a longer time. 400 questionnaires were distributed among the workers of logistic firms in the above-mentioned big cities of Pakistan. Only 298 responses were acquired out of which 258 were workable. Data were analyzed using SPSS-23.

Main Findings: Findings reveal that the moderating role of ICT is insignificant on the relationship between e-Payment and Customer Satisfaction and the use of ICT enhances the Service Quality of Logistics and Customer Satisfaction. The beneficiary of the current research would be the logistics firms of Pakistan as it encompasses different aspects influencing logistic customer satisfaction. Logistic service quality is directly linked to the customer, so the current study can benefit the logistic firm in how to retain customers and ultimately how to increase profitability.
\end{abstract}

Implications/Applications: Current research also describes the utilization of Information and Communication Technology so organizations can design their system according to the modern framework of technology.

Novelty/Originality of this study: This research study is based on different logistic services of major cities of Pakistan. The direct impact of independent variables on a dependent variable will be studied along with the moderating effect of Use of ICT on the direct relationships. The practice of logistic services has been changed due to the emergence of the concept of service quality and relationship marketing. Traditionally, logistics has been thought to be a bridge between production and consumption.

Keywords: Logistics Service Quality, E-payment, E-traceability, ICT, Customer Satisfaction.

\section{INTRODUCTION}

With the continuous innovation in the services sector of Pakistan, the logistic industry has also been flourished drastically. Previously, the use of technology was limited, but gradually, it has spread to an extent that no one can imagine the industry without technical support. Today, everyone is accustomed to online things and wants to access everything online. Such huge progress has speeded up the logistics and supply chain processes which have ultimately reduced cost, time consumption, and errors. This advancement has benefited shipment tracking, trucking transportation, and international transportation, including both air and ocean domains. The framework of the supply chain usually comprises third-party logistics service providers, express couriers, companies of minor transportation, rail and sea transportation, multi-modal transport operators, and intermodal terminal infrastructures. This entire complex system requires the latest ways of managerial support and reliable networks for information handling to perform coherently for the sake of customer satisfaction. Failure to do this results in cost-hike and poor services (Perego, Perotti, \& Mangiaracina, 2011).

Current research work consists of five variables; three independent variables, one moderator, and one dependent variable. Independent variables are E-Traceability, E-Payment, and Logistic Service Quality. The moderator is the Use of ICT (Information and Communication Technology), whereas the dependent variable is Customer Satisfaction. This research study is based on different logistic services of major cities of Pakistan. The direct impact of independent variables on a dependent variable will be studied along with the moderating effect of Use of ICT on the direct relationships. The practice of logistic services has been changed due to the emergence of the concept of service quality and relationship marketing. Traditionally, logistics has been thought to be a bridge between production and consumption. From this perspective, a logistic function has been considered as a cost-generating tool with no differentiation. This trend started to change in the 1990s as the analysis of logistics to deliver quality begun and it rendered customer satisfaction (Richey et al., 2011). 
The use of information technology has revolutionized every industrial sector, including logistics and supply chain. The organizations related to the supply chain can acquire useful information and utilize it to enhance the efficiency, reliability, and profitability of their company. Information and Communication Technology helps coordinate different activities related to the supply chain. Additionally, the cost of the supply chain processes can also be reduced using ICT. Companies should focus on developing data management capabilities which include the integration of the manufacturer's data and the retailer's data. It also encompasses the creation of invoices, generation of store credits, and issuance of management reports (Richey et al., 2011). In this way, companies would be able to apply the acquired information to streamline internal processes and support the planning of different supply chain levels (Wangenheim, 2003).

In logistic organizations, customer satisfaction is as important as in any other service sector organization. The business of logistics covers diverse geographical locations due to which the segment of customer satisfaction is sometimes ignored. This problem is being constantly tried to be mitigated (Waseem-Ul-Hameed, Nadeem, Azeem, Aljumah, \& Adeyemi, 2018). Another research carried out by Rollins, Pekkarinen, and Mehtala (2011) that it is important to establish a close relationship between the logistic service provider and the buyer of the logistic service in order to enhance customer knowledge sharing and satisfaction. Another problem in logistic services is electronic traceability which is the ability to verify the location, history, or application of any item. Usually, it was done by documented records (Waseem-Ul-Hameed et al., 2018). Similarly, electronic payment is one of the highest concerns in the ecommerce business, especially, due to the increasing number of cybercrimes in Pakistan. Although, banks and organizations try to provide secure systems for payments but information hacking, unfortunately, has become a common practice leading to scepticism in the customers. Another variable of the current research also focuses on the relationship between Logistic Service Quality and Customer Satisfaction.

\section{Significance of the study}

The beneficiary of the current research would be the logistics firms of Pakistan as it encompasses different aspects influencing logistic customer satisfaction. Firms will be better off if they optimize the driving factors of customer satisfaction. Current research also describes the utilization of Information and Communication Technology so organizations can design their system according to the modern framework of technology. As there are three independent variables; e-traceability, e-payment, and service quality. Two of the variables are directly related to modern ICT systems which would ultimately explain the provoking dimensions of customer satisfaction. Logistic service quality is directly linked to the customer, so the current study can benefit the logistic firm in how to retain customers and ultimately how to increase profitability.

\section{Research Objectives}

There are the following research objectives of the study:

1. To find out the relationship between e-Traceability and Customer Satisfaction

2. To find out the relationship between e-Payment and Customer Satisfaction.

3. To find out the relationship between Logistic Service Quality and Customer Satisfaction.

4. To verify the moderating effect of Use of ICT on eT-CS relationship.

5. To verify the moderating effect of Use of ICT on eP-CS relationship.

6. To verify the moderating effect of Use of ICT on LSQ-CS relationship.

\section{LITERATURE REVIEW}

\section{E-Payment}

Jafari, Bagheri, and Hosseinzadeh (2013) have assessed the highlights of various e-payment frameworks from the perspective of Iranian clients. Aftereffects of this examination showed that from the perspective of Iranian clients, security and trust are the most significant highlights, and the capacity to change and the track is the least significant highlights of e-payment frameworks. The highlights indicated by various clients for e-payment frameworks are viewed as significant in structuring new frameworks, yet additionally, cause its acknowledgment among clients. In an article

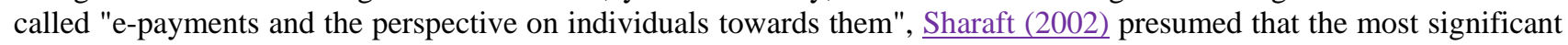
and successful components of e-payment techniques are the supporters' nature, culture, and propensity to utilize them. Other scholars such as Pratama and Utama (2019) and Fatonah, Yulandari, and Wibowo, (2018) also agreed with the significance of culture and usability of e-payment techniques.

An article called "assessing viable variables of choosing e-payment frameworks from the customers' view", demonstrated that among payment frameworks, customers will in general select the strategy that are significant, agreeable and productive both genuinely and thinking about innovative, monetary, and legitimately points of interest. In an article called "e-banking and its impact on powerful factors of customer satisfaction", Akbarian and Vakili (2011) demonstrated that there is a critical connection between utilizing e-banking administrations and customer satisfaction. The same findings were obtained in a recent study by Alhammadi and Tariq (2020). Whereas on the other hand, when 
the price of a product is high, then individuals do not rely on e-payment and consider it risky (Choi, 2020; Ho, See-To, \& Chiu, 2020).

In an article called examining the nature of the gave administrations by e-banking web entrances intention, Regattieri, Gamberi, and Manzini, (2007) assessed the nature of the web banking administrations from the perspective of customers. Results showed that customers were happy with four records, counting reliability, openness, protection/security, responsibility, and undertaking execution, and disappointed with the easy-to-use file. Subsequent to assessing the nature of electronic administrations on customers' satisfaction and return, after effects of Regattieri et al. (2007) demonstrated that effectiveness, protection, and responsibility are powerful and openness, administration finish, and contact had no impact on customer satisfaction; in the end, customer satisfaction influences customers in reusing the electronic administrations.

Subsequent to assessing the electronic satisfaction of business visionaries with the presentation of card per user gadgets (POS) in little and medium organizations (SMEs). Lindh, Dahlin, and Hadjikhani (2008) inferred that the security of utilizing card perusers has the most effect on the electronic satisfaction of business visionaries. Besides, trust has the most impact on the electronic satisfaction of business people. In an article called "e-banking strategies and customer satisfaction - a contextual analysis in Bosona and Gebresenbet (2013) demonstrated that concerning customer needs, ebanking specialist co-ops neglected to make customers mindful of e-banking and utilizing outdated or not refreshed innovations. In the wake of assessing speculations, it was indicated that there is a connection between age gatherings, occupation types, and some e-banking angles. He reasoned that to impact customers in Botswana, banks ought to engage in all complexities and subtleties of e-banking to augment their benefit.

In an article called "the examination of satisfaction with e-banking administrations among customers with and without an instructive degree in Penang, Malaysia", (Zeithaml, Bitner, \& Gremler, 2006) inferred that notwithstanding the challenges, expenses, and some security worries among customers without an instructive degree, just as some security worries among customers with an instructive degree, the two gatherings are happy with some e-payment benefits in Malaysia. What's more, from the perspective of individuals with and without an instructive degree, the most significant concerns are separately the security issues and trouble to work with e-payment administrations.

$\mathbf{H}_{\mathbf{0 1}}$ : e-Payment has a positive relationship with Customer Satisfaction.

\section{Logistics Service Quality}

Improving customer service is a progressing focal point of logistics research and practice. Sidhvan (1980) noticed that customer service has been estimated by stockout levels, request cycle components, and framework exactness, which falls into two general classes: stock ability (culmination, and fill rate), and request process duration (length and dependability of the request cycle). Later work likewise included practicality (Tse \& Wilton, 2001); be that as it may, these measures can be created with little support from the customer. As per Wangenheim (2003), these quantitative measures don't totally clarify customer evaluations of provider service levels. By and by, be that as it may, numerous organizations are not in direct contact with customers, depending on these inside created proportions of execution to deduce customer feelings (Wangenheim, 2003). While conventional logistics service research concentrated on "hard" measures to survey customer prerequisites (e.g., fill rates, on-time conveyance, request process duration), creating "customer-centred" logistics service quality (LSQ) implies understanding service from the customer's viewpoint, which can improve service contributions and be a separation device.

Progressively, providers are currently attempting to comprehend what their customers need other than accessibility, practicality, and unwavering quality (Wangenheim, 2003). Setiawan (2019) argued that service quality in logistics can be a vital competitive advantage for any firm. One basic component that recognizes the best firms is the way that they remotely confirm customer observations. In the logistics writing, Stark talks about the change from the large-scale manufacturing attitude ("doing things ideal"), to firms that worth customer closeness and can give larger amounts of service adequacy (the capacity to "do the correct things"). Logistics research has connected advertising apparatuses, explicitly those in the service quality writing, to assess logistics service utilizing customer impression of supplier execution instead of depending on suppliers' self-detailed execution markers (Malik \& Sinha, 2020, Lubera, 2019). In advertising, the focal point of service execution has been on service quality or the assessment of service execution. The definition and estimation of service quality have involved an unmistakable position in the services advertising writing. The service quality worldview began with a subjective report, where the distinctions in the view of service among supervisors and shoppers were analysed.

As a result of the developing power of rivalry, showcasing systems have changed from concentrating on drawing in new customers to concentrating on verifying and improving customer devotion. From a supply chain viewpoint, there is an expanding accentuation to frame collective associations with select exchanging accomplices (Verhoef, Franses, \& Hoekstra, 2002), so a significant key result for providers in the supply chain is the fulfillment of customer steadfastness. Even though there is much research on customer dedication, it is hard for organizations to actualize it since a lot of it is vague and conflicting. While the definitions and estimation scale extensively change in clarifying unwaveringness, the wonder appears to show itself in two unmistakable ways: dependability aims and steadfastness frames of mind (Ganesh, Arnold \& Reynolds, 2000). What this implies, at that point, is that dependability includes both conduct and feeling. 
Steadfastness is the conduct has generally centred around a customer's recurrent buy conduct that is activated by showcasing exercises. Nonetheless, the thinking behind enthusiastic steadfastness is that recurrent buys alone don't really demonstrate genuine unwaveringness. Tzokas and Saren (1997) recommend that genuine, faithful connections among firms and customers are made by the association's capacity to interface sincerely and fashion long-haul bonds with customers.

$\mathbf{H}_{\mathbf{0 2}}$ : Logistic Service Quality has a positive relationship with Customer Satisfaction.

\section{E-Traceability}

An organization witness tremendous money-related issues and brand misfortune when it doesn't ready to convey the item at the correct time in the market. Legitimate generation control process deals with the request as well as encourages the organization to develop the item structuring procedure and logistics traceability is the best device to accomplish this ( $\mathrm{Li}$, Lv, Xiang, Sun, \& Sun, 2020; Thakur, Tveit, Vevle, \& Yurt, 2020). Programmed traceability framework has an incredible effect on the supply chain from decreasing the benefit misfortune to the quality control (Liu et al., 2008). In their work, the creators opine that the traceability framework causes the on-screen characters to examine the customer conduct and gives the best possible learning of out-of-stock circumstances (Liu et al., 2008).

The detectable information can be utilized to improve the business procedure to accomplish and execute better creation control and stock administration (Dasaklis, Casino, \& Patsakis, 2020). The creators additionally opine that the advantages of the traceability framework incorporate generation proficiency through by and large quality improvement, advancement of the executives, and dynamic evaluating and improvement of supply chain logistics and dissemination process. In another work, a RFID based traceability framework is executed to deal with the logistics procedure of reseller's exchange car parts appropriation of a Tibetan organization (Samarasinghe, Nishantha, \& Shutto, 2009). In this work, the creator contrasted the as-is model and the to be model of the logistics procedure from make request through make receipt, pick and sort products and so on to transportation and demonstrated that the proposed traceability model decreases the time spent on this procedure.

Chen, Shen, Hung, and Wang (2004) recognized the prerequisites of the traceability framework and proposed EPC/RFID based traceability procedure and design model (Minbo \& Chen, 2009). The supply chain is intricate today and in that capacity, each entertainer must act successfully to make the supply chain productive. A traceability framework dependent on EPC worldwide system was created to gather RFID information and RFID occasions to follow and record the logistics data (Regattieri et al., 2007). Numerous works propose that RFID is significant and effective apparatuses to build up the traceability framework (Tian, Zheng, \& Meng, 2018). An RFID framework comprises of a receiving wire and a handset, which reads the radio recurrence and moves the data to a preparing gadget, and a transponder, or tag, which is an incorporated circuit containing the RF hardware and data to be transmitted. The required item's data are put away in the RFID label, which is recognizable by the RFID per user anytime in the supply chain inside 10 meters range. Dissimilar to standardized identifications, there shouldn't be an immediately viewable pathway between the tag and per user.

Here the data from the crude material social event, handling, pressing, putting away, and circulating is followed and put away in the database for further access by the partners in the supply chain from item maker to buyers (Chen et al., 2004). Individuals are increasingly worried to know the quality data uncommonly for the sustenance item before utilizing it. So an appropriate framework must be actualized that will give all the data to the clients at the mentioned time. Boston et al in their work opines that traceability is a vital piece of logistics the board and propose another meaning of sustenance traceability expressing that it is the piece of logistics the executives that catch, store and convey the satisfactory data (Bosona \& Gebresenbet, 2013).

In this work, the creator dissected the main impetus, advantages, and hindrances of actualizing nourishment traceability framework and recommended that chain traceability is required, which is the piece of coordinated logistics framework. They additionally recommended that further inquires about have to be done on the area of innovative perspectives, connect between traceability framework and generation framework, the institutionalization of data trade, mindfulness creation, and the effectiveness of traceability framework (Bosona \& Gebresenbet, 2013). The general impression is that traceability is exceptionally helpful for the enhancement of generation procedure, and it will be increasingly gainful if this framework is coordinated with logistics executives because of the intricate idea of the supply chain.

$\mathbf{H}_{03}$ : e-Traceability has a positive relationship with Customer Satisfaction.

\section{Customer Satisfaction}

Customer satisfaction was characterized by Oliver (1999) as the degree of achievement of some longing, needs, objective, or another superb end express that outcomes from an exact trade between the customer and a firm. It was additionally characterized by Zeithml and Bitmer $(1996 ; 2003 ; 2006)$ as the customers' satisfaction response, which is a judgment that an item or service highlight results to the fulfilling level of utilization related satisfaction, including the level of under or over satisfaction. Customer maintenance was characterized by Shahzore (2002) as the ability of the association's idea to its customers to buy its items or services over a predefined period. Saqib (2003) characterized 
customer maintenance as a state which uncovers the shopper's unwaveringness to a brand and the ensuing declined propensity to switch brand.

Generally, customer satisfaction remained a point of interest for the scholars and practitioners from the management and marketing domain; a lot of work has been done in highlighting the significance and importance of customer satisfaction for the organizations (Eldabet, 2019; Hartono, 2019). Extensive research highlights that when customers are happy and content with the services provides, they show satisfaction, loyalty, and commitment to the brand (Mansoor, Awan \& Syed, 2020). Whereas, non-satisfied customers spread negative word of mouth which harms the business in the long run (Barari, Ross, \& Surachartkumtonkun, 2020). Lindh et al. (2008) in their examination, how can IT Impact Business Relationships? Gathered and dissected information from 354 business connections on the Swedish business-to-business advertise, to respond to the inquiry if and how IT impacts social trade connections.

Lindh et al. (2008) concentrated on correspondence and relationship, the outcome demonstrates that business connections wherein IT increments or diminishes the requirement for individual gatherings to a higher degree have a generally more elevated amount of utilization of IT in the trades. Be that as it may, the connection between the degree of utilization of IT and its impact on the requirement for individual gatherings isn't straight, which implies that although the requirement for individual gatherings changes with more elevated amounts of IT use in trades, it is obscure when or why the requirement for gatherings increments or diminishes. This demonstrates, to certain organizations, IT lessens individual connection while others take the view that IT builds individual communication (Lindh et al., 2008). It very well may be presumed that however this examination is identified with this exploration targets, it is uncertain as it neglected to state whether the pace of those that help the way that IT decreases individual collaboration is higher than those that contradicted it.

In 2007, an examination led in the United States and Canada by Kamran demonstrates IT sway on business to discover changes in the business that are driven by IT in a broad field of business ventures, watched four factors, correspondence, and relationship, accommodation, business procedure, and globalization. Kamran learned that organizations are encountering radical inner adjustment, in that capacity, the manners in which organizations cooperate with colleagues and customers had changed. However, the pace of progress is conceivably not as fast as recommended by the highwater-mark examples that are shown in the prevalent business press. All things considered, the progressions are without inquiry both predominant and ongoing (Zack, 2005). This exploration is important, yet it will be increasingly profitable if it had expressed the (rate) at which organizations are changing with its impact. Going before research by Lewin, Lippitt, and White, (1939) found that a firm that grasps IT will profit development, cost decrease, advancement, organization, and separation points of interest produced by the IT. They presume that IT upgrades data availability, correspondence, and union examples. Lewin et al. (1939) contend further that previously mentioned advantages will encourage connections between firms inside similar ventures and also upgrade firms' intensity in worldwide markets.

\section{Use of ICT}

According to (Dawe, 1994), several managers emphasize the importance of information technology, stating that it is the single most important contributor that affects logistics and supply chain. Bowersox, Daugherty, Droge, Rogers, and Wardlow, (2015) pointed out ten differentiators between successful logistic organizations and the ones that stood at the average level. The ability to invest in the highest degree of information technology is one of those differentiators. Another research carried out by Sakchutchawan, Hong, Callaway, and Kunnathur (2011) say that there are several innovations in the field of logistics, including electronic data interchange (EDI), radio frequency identification (RFID), and cross-docking. However, RFID has been observed to get a lot of attention in the logistics industry. The reason is this innovation allows shippers and customers to acquire data about consignments during the whole shipping process. Radio Frequency Identification tags have special tracking devices to identify every item which lets the stakeholders locate their product and estimate the delivery time.

Another innovative approach is to implement wireless networks in warehouses. This upgradation can produce tremendous results if done appropriately. It is advised to take advantage of wireless networks in the warehouses to replace manual human operation, which is prone to create errors, with the latest technology to save time. Activities like order processing and inventory control can be replaced successfully. Wireless scanners or RFID technology send data to update stock information without rendering excessive cost along with saving precious time. This process eliminates the requirement of manual processes that needed more time and always had a risk of making errors. With such advances in the field of technology, third-party logistics strive for the latest and optimum ways to manage their supply chain businesses successfully. Another important aspect to consider is last-mile logistics in which (Ranieri, Digiesi, Silvestri, \& Roccotelli, 2018) contributed significantly towards the literature by focusing on the reduction of externalities cost. Such cost includes pollution and congestion costs etc, which have been hiked in recent years. In addition to that, advancements like globalization and online shopping have introduced new trends in the transportation of freight. It is a fact that the last mile logistics is comprised up to $28 \%$ of the total cost of delivery.

This research also suggests that last-mile delivery problems are dealt with the help of Information and Communication Technology and Information Transport Systems. Another application of ICT in the logistic industry is ICT for sustainability (ICT4S). Bates et al. (2018) also pointed out the issue of pollution, carbon emission, and congestion by the 
sector of parcel delivery that also comes under the logistic industry. The main focus of the research is "silly season" and it has provided its vision of a digital sustainable logistic platform that is possible with the use of ICT4S. Keeping in view the indirect impact on consumers, it can be assumed that the environmental problems may not impact customer satisfaction straight away, but in the longer terms, it can enhance the corporate social responsibility sector of a logistic firm.

$\mathbf{H}_{\mathbf{0 4}}$ : Use of Information and Communication Technology moderates the relationship between e-Payment and Customer Satisfaction.

$\mathbf{H}_{\mathbf{0 5}}$ : Use of Information and Communication Technology moderates the relationship between Logistic Service Quality and Customer Satisfaction.

$\mathbf{H}_{\mathbf{0 6}}$ : Use of Information and Communication Technology moderates the relationship between e-Traceability and Customer Satisfaction.

\section{Conceptual Model}

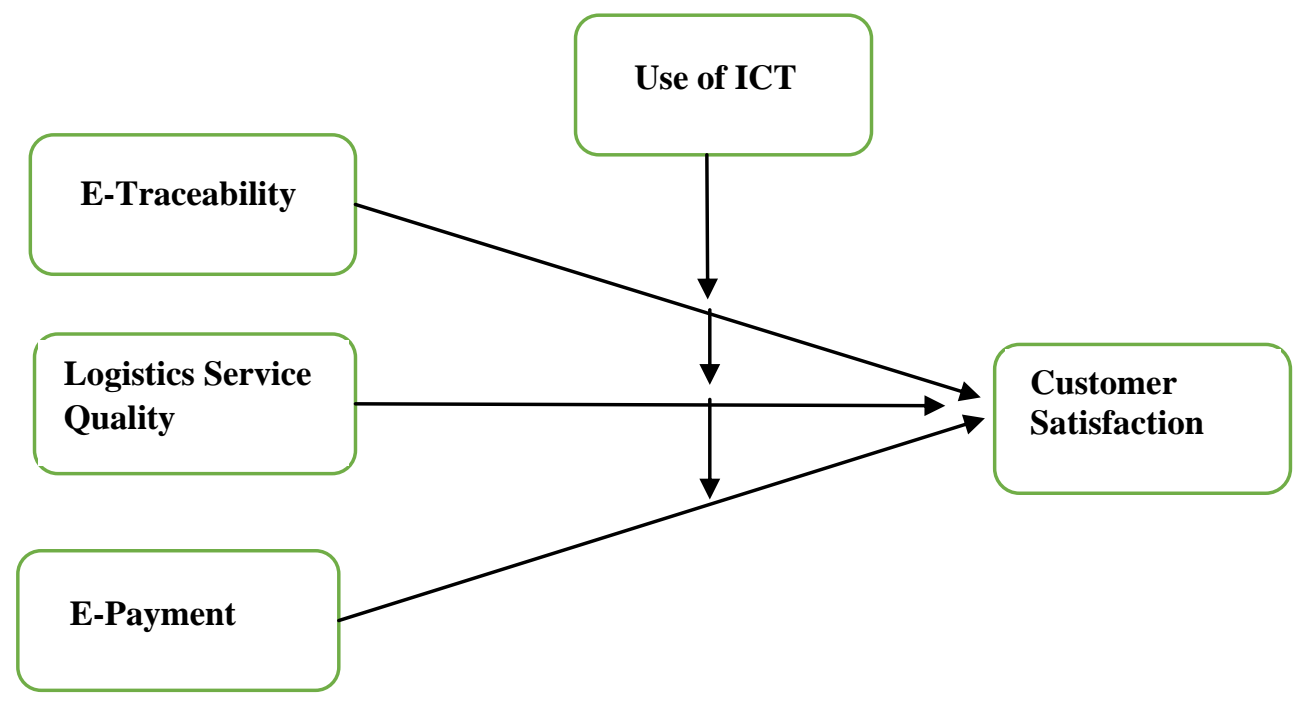

Figure 1: Conceptual Model

Source: Author Analysis

\section{RESEARCH METHODOLOGY}

A quantitative approach has been used to examine different supermarkets located in major cities (Peshawar, Rawalpindi, Islamabad, Multan, Karachi, and Lahore) of Pakistan. Several logistic firms were selected from all over the country to collect and analyze the data. Initially, interviews were conducted with their managers and supervisors; later on, personal surveys were conducted through which questionnaires were filled. It is a field study because participants, i.e. the managers and the supervisors were contacted on their jobs to fill the instrument (questionnaire) in their natural work environment.

Data was collected during several time frames. The data was cross-sectional. Due to the involvement of different geographical locations, data collection took a long time. 400 questionnaires were distributed among the workers of logistic firms in the above-mentioned big cities of Pakistan. Out of 400, only 298 responses were acquired out of which 258 were workable. All responses were acquired by a "self-report" measure in which the responses were taken from a five-point Likert scale ranging from 5 being very great extent, $4=$ great extent, $3=$ moderate extent, $2=$ little extent to 1 being very low extent. There were overall 29 questions to measure the impact of Information Communication Technology on Customer Satisfaction. Since English is a commonly used language and medium of instruction in Pakistan, so survey questionnaires were also prepared in English.

\section{Sample and Descriptive Statistics}

There are a total of 191 males and 67 females' respondents. Most respondents were post-graduates and make a total of 170

out of 258. 87 persons have completed 16 years of education. The remaining 1 had completed a doctorate degree. Similarly, there are different age categories of respondents. Most of them were in the range of 26 to 35 years, i.e. 128.87 were 36 to 45 years old; 25 individuals fall in the category of 46 years and above. In terms of experience, the majority of the respondents were experienced personnel having professional experience between 4 to 7 years. 70 were 0 to 3 years, 35 were 8 to 10 years and only a single participant was more than 10 years experienced. 
Table 1: Gender Studies

\begin{tabular}{ll}
\hline & No. of respondents \\
\hline Male & 191 \\
\hline Female & 67 \\
Total & 258 \\
\hline
\end{tabular}

Table 2: Reliability Analysis

\begin{tabular}{lll}
\hline & No. of items & Cronbach's Alpha \\
\hline Trace & 6 & 0.787 \\
\hline Payment & 6 & 0.733 \\
\hline LSQ & 6 & 0.784 \\
\hline ICT & 5 & 0.713 \\
\hline CS & 6 & 0.708 \\
\hline
\end{tabular}

According to (George, 1989), the acceptable value of Cronbach's Alpha 0.7, and above which means that the instrument is reliable.

\section{Results/ Findings}

Table 3: Correlation Analysis

\begin{tabular}{llllllll}
\hline & & Mean \pm SD & E-Trace & E-Payment & LSQ & ICT & CS \\
\hline 1. & E-Trace & $4.60 \pm 0.44$ & 1 & & & & \\
\hline 2. & E-Payment & $4.60 \pm 0.42$ & $0.317^{*}$ & 1 & & & \\
\hline 3. & Logistics SQ & $4.70 \pm 0.45$ & $0.145^{*}$ & $0.688^{*}$ & 1 & & \\
\hline 4. & ICT & $4.60 \pm 0.46$ & $0.151^{*}$ & $0.599^{*}$ & $0.784^{*}$ & 1 & \\
\hline 5. & CS & $4.66 \pm 0.41$ & $0.128^{*}$ & $0.666^{*}$ & $0.650^{*}$ & $0.487^{*}$ & 1 \\
\hline
\end{tabular}

* Significance level is 0.1 (2-tailed)

Table 4: Regression Analysis

\begin{tabular}{lllll}
\hline Predictor(s) & \multicolumn{4}{l}{ Customer Satisfaction } \\
\hline Step I & $\mathrm{B}$ & $\mathrm{R}^{2}$ & $\Delta \mathrm{R}^{2}$ & Sig. \\
\hline E-Trace & & & & \\
\hline E-payment & $0.118^{*}$ & 0.016 & 0.128 & 0.040 \\
\hline Logistics SQ & $0.636^{*}$ & 0.443 & 0.666 & 0.000 \\
\hline Step-II & $0.590^{*}$ & 0.422 & 0.650 & 0.000 \\
\hline E-Trace X ICT & & & & \\
\hline E-Payment X ICT & $0.098^{*}$ & 0.262 & 0.512 & 0.000 \\
\hline Logistics SQ X ICT & $-0.001 *$ & 0.522 & 0.472 & 0.964 \\
\hline$* \mathrm{p} \leq 0.1$ & & 0.429 & 0.655 & 0.081 \\
\hline
\end{tabular}

\section{DISCUSSION/ ANALYSIS}

The relationship between all independent and dependent variables is significant as the value of significance is less than 0.1 for all variables. It indicates that e-traceability, e-payment, and logistic service quality add value to customer satisfaction. Programmed traceability framework has an incredible effect on the supply chain from decreasing the benefit misfortune to the quality control (Liu et al., 2008). Similarly, the outcome of the variable e-payment is also supported by the literature; In an article called "e-banking and its impact on powerful factors of customer satisfaction", Akbarian and Vakili (2011) demonstrated that there is a critical connection between utilizing e-banking administrations and customer satisfaction. According to Saura, Frances, Contri, and Blasco (2008) a sample of 194 companies show that the aspects of Logistic Service Quality, i.e. timeliness, personnel, order quality, and information have a positive impact on the satisfaction of the customer companies. As far as the role of ICT is concerned as a moderator, only the e-payment variable shows insignificant behaviour. It can be assumed the people in Pakistan either think E-payment methods still unreliable despite the advancement of technology, or most customers like to pay cash due to some reason. Enormous research illustrates that when consumers are satisfied and pleased with all the services provides, they demonstrate happiness, loyalty, and dedication to the brand (Mansoor, Awan \& Syed, 2020). Except that, non-satisfied customers spread bad word of mouth which hurts the organization in the long term (Barari, Ross, \& Surachartkumtonkun, 2020).

According to previous studies, several managers emphasize the importance of information technology, stating that it is the single most important contributor that affects logistics and supply chain. 
To summarize the results, all the hypotheses are supported except $\mathrm{H}_{04}$, i.e. "Use of ICT moderates the relationship between e-Payment and Customer Satisfaction.

\section{RECOMMENDATIONS}

There are certain recommendations to the logistic services of Pakistan. First of all, these companies should ensure a secure payment method to satisfy the customers about modern e-Payment system. Special measures should be taken to enhance the protection of transactions. In addition to that, the up-gradation of technology is as important as its adoption, as antiquated technology will not help to achieve long-term goals.

\section{LIMITATIONS AND FUTURE WORK}

While carrying out the current research, few limitations were also considered. There was a certain amount of data available, as several companies were reluctant to participate due to privacy issues. Also, this research encompasses only major cities of Pakistan. Results for minor cities and remote areas could be different.

In the future, researchers can diversify the current research by adding more geographical locations to it. In addition to that, other areas of problems can be added, for instance, transit time and distribution rate, etc.

\section{CONCLUSION}

To conclude, this research was carried out in logistic companies of major cities of Pakistan in order to collect data on ePayment, Logistic Service Quality, e-Traceability being the dependent variables. Also, other variables were studied, including Customer Satisfaction and Use of Information and Communication Technology. Results show that the moderator does not affect the relationship between e-Payment and Customer Satisfaction. All other hypotheses were supported.

\section{AUTHORS CONTRIBUTION}

Dr. Shahzad Ahmad Khan and Ammar Husain wrote the research paper and design the organization of the article. Ali Haider and Mubashar Hassan Zia perform the statistical analyses, interpretations, and technical parts. All the author(s) have a significant contribution to the research article.

\section{ACKNOWLEDGEMENT}

We would like to thank all the independent reviewers of HSSR who conducted a feasibility study of our research work.

\section{REFERENCES}

1. Akbarian, R., \& Vakili, T. (2011). Evaluation of factors affecting electronic payment systems by customers. In the First Regional Conference on New Approaches in Computer Engineering and Information Technology, Rudsar.

2. Alhammadi, A. A., \& Tariq, M. U. (2020). The Impact of Quality E-payment System on Customer Satisfaction. Journal of Critical Reviews, 7(15), 5438-5447.

3. Barari, M., Ross, M., \& Surachartkumtonkun, J. (2020). Negative and positive customer shopping experience in an online context. Journal of Retailing and Consumer Services, 53, 101985. https://doi.org/10.1016/j.jr etconser.2019.101985

4. Bosona, T., \& Gebresenbet, G. (2013). Food traceability as an integral part of logistics management in food and agricultural supply chain. Food Control, 33(1), 32-48. https://doi.org/10.1016/j.foodcont.2013.02.004

5. Bowersox, D. J., Daugherty, P. J., Droge, C. L., Rogers, D. S., \& Wardlow, D. L. (2015). An Examination of North American Leading Edge Logistics. In Proceedings of the 1989 Academy of Marketing Science (AMS) Annual Conference (pp. 445-449). Springer, Cham. https://doi.org/10.1007/978-3-319-17055-8 90

6. Chen, J. P., Shen, T. T., Hung, Y. T., \& Wang, L. K. (2004). Pollution prevention. In Wang, L. K., Hung, Y. T., Lo, H. H., \& Yapijakis, C. (Eds.). Handbook of industrial and hazardous wastes treatment. CRC Press.

7. Choi, T. M. (2020). Mobile-App-Online-Website Dual Channel Strategies: Privacy Concerns, E-Payment Convenience, Channel Relationship, and Coordination. IEEE Transactions on Systems, Man, and Cybernetics: Systems. https://doi.org/10.1109/TSMC.2019.2961979

8. Dasaklis, T. K., Casino, F., \& Patsakis, C. (2020). A traceability and auditing framework for electronic equipment reverse logistics based on blockchain: the case of mobile phones. In 2020 11th International Conference on Information, Intelligence, Systems and Applications (IISA (pp. 1-7). IEEE.

9. Eldabet, M. M. (2019). Proposed framework for the factors and determinants of the identification of targeted customers for small and medium enterprises, applying to hotel and restaurant services. International Journal of Business and Economic Affairs, 4(5), 254-263. https://doi.org/10.24088/IJBEA-2019-45005

10. Fatonah, S., Yulandari, A., \& Wibowo, F. W. (2018). A review of e-payment system in e-commerce. In Journal of Physics: Conference Series (Vol. 1140, No. 1, p. 012033). IOP Publishing. https://doi.org/10.1088/1742$\underline{6596 / 1140 / 1 / 012033}$ 
11. Ganesh, J., Arnold, M. J., \& Reynolds, K. E. (2000). Understanding the customer base of service providers: An examination of the differences between switchers and stayers. Journal of Marketing, 64(3), 65-87. https://doi.org/10.1509/jmkg.64.3.65.18028

12. George, L. K. (1989). Stress, social support, and depression over the life-course. In K. S. Markides \& C. L. Cooper (Eds.), Aging, stress and health (p. 241-267).

13. Hartono, S. S. (2019). The effect of expected and perceived service quality on customer satisfaction: Optical retail in Indonesia. International Journal of Business and Administrative Studies, 5(2), 186-198. DOI: https://doi.org/10.20469/ijbas.5.10002-4

14. Ho, K. K., See-To, E. W., \& Chiu, D. K. (2020). "Price Tag” of Risk of Using E-Payment Service. Journal of Internet Commerce, 19(3), 324-345. https://doi.org/10.1080/15332861.2020.1742482

15. Jafari, A., Bagheri, F., \& Hosseinzadeh, N. (2013). solutions to increase customer satisfaction by fuzzy ANP approach, BSC, and fuzzy TOPSIS (Case Study: Electronic payment company). In the First National Conference on the Development of Monetary Management and Banking, Tehran, Iran.

16. Lewin, K., Lippitt, R., \& White, R. K. (1939). Patterns of aggressive behavior in experimentally created "social climates". The Journal of Social Psychology, 10(2), 269-299. https://doi.org/10.1080/00224545.1939.9713366

17. Li, X., Lv, F., Xiang, F., Sun, Z., \& Sun, Z. (2020). Research on key technologies of logistics information traceability model based on consortium chain. IEEE Access, 8, 69754-69762. https://doi.org/10.1109/A CCESS.2020.2986220

18. Lindh, C., Dahlin, P., \& Hadjikhani, A. (2008). How Does Information Technology Impact on Business Relationships? The Need for Personal Meetings. In 24th IMP-conference, Uppsala, Sweden.

19. Liu, C. S., Trappey, C. V., Trappey, A. J., Hung, A. Y., Huang, A. Y., \& Lee, W. T. (2008). Analysis and design of a supply chain logistics hub for aftermarket automotive parts distribution. In 2008 International Conference on Service Systems and Service Management (pp. 1-5). IEEE. https://doi.org/10.1109 /ICSSSM.2008.4598548

20. Lubera, R. (2019). The concept of logistic attractiveness - Theoretical basis. International Journal of Humanities, Arts and Social Sciences, 5(3), 109-116. https://doi.org/10.20469/ijhss.5.20004-3

21. Malik, R. K. \& Sinha, G. K. (2020). Sustainable logistics in automobile passenger vehicle manufacturing organizations. International Journal of Humanities, Arts and Social Sciences, 6(1), 1-9. https://doi.org/ 10.20469/ijhss.6.20001-1

22. Mansoor, M., Awan, T. M., Syed, F (2020). Positive emotions as underlying mechanism between customer gratitude and behavioural intentions. Journal of Administrative and Business Studies, 6(1). 9-20. https://doi.org/10.20474/jabs-6.1.2

23. Minbo, L., \& Chen, C. (2009). Rfid complex event processing mechanism for logistics tracking and tracing. In 2009 International Forum on Computer Science-Technology and Applications (Vol. 3, pp. 44-48). IEEE. https://doi.org/10.1109/IFCSTA.2009.249

24. Oliver, R.L. (1999) Whence consumer loyalty. Journal of Marketing, 63, 33-34. https://doi.org/10.1177/00222429990634s105

25. Perego, A., Perotti, S., \& Mangiaracina, R. (2011). ICT for logistics and freight transportation: A literature review and research agenda. International Journal of Physical Distribution \& Logistics Management, 41(5), 457-483. https://doi.org/10.1108/09600031111138826

26. Pratama, J., \& Utama, A. A. (2019). Business process analysis for transfer payment transaction case study: An LPG distributor company in Bandung. International Journal of Business and Administrative Studies, 5(2), 8496. https://doi.org/10.20469/ijbas.5.10004-2

27. Ranieri, L., Digiesi, S., Silvestri, B., \& Roccotelli, M. (2018). A review of last-mile logistics innovations in an externalities cost reduction vision. Sustainability, 10(3), 782-788. https://doi.org/10.3390/su10030782

28. Regattieri, A., Gamberi, M., \& Manzini, R. (2007). Traceability of food products: General framework and experimental evidence. Journal of Food Engineering, 81(2), 347-356. https://doi.org/10.1016/j.jf oodeng.2006.10.032

29. Richey Jr, R. G., Hilton, C. B., Harvey, M. G., Beitelspacher, L. S., Tokman, M., \& Moeller, M. (2011). Aligning operant resources for global performance: An assessment of supply chain human resource management. Journal of Management and Organization, 17(3), 364-382. https://doi.org/10.5172 /jmo.2011.17.3.364

30. Rollins, M., Pekkarinen, S., \& Mehtälä, M. (2011). Inter-firm customer knowledge sharing in logistics services: An empirical study. International Journal of Physical Distribution \& Logistics Management, 41(10), 956-971. https://doi.org/10.1108/09600031111185239

31. Sakchutchawan, S., Hong, P. C., Callaway, S. K., \& Kunnathur, A. (2011). Innovation and competitive advantage: model and implementation for global logistics. International Business Research, 4(3), 10-21. https://doi.org/10.5539/ibr.v4n3p10

32. Samarasinghe, R., Nishantha, G. G. D., \& Shutto, N. (2009, December). Total traceability system: A sustainable approach for food traceability in SMEs. In 2009 international conference on Industrial and Information Systems (ICIIS) (pp. 74-79). IEEE. https://doi.org/10.1109/ICIINFS.2009.5429887

33. Saqib, (2003). Information Technology in Business. New York, NY: Cengage Learning. 
34. Saura, I. G., Frances, D. S., Contri, G. B., \& Blasco, M. F. (2008). Logistics service quality: A new way to loyalty. Industrial management \& data systems. Industrial Management \& Data Systems, 108(5), 650-668. https://doi.org/10.1108/02635570810876778

35. Setiawan, S. B. (2019). Sustainability and the competitive advantage: The perspective of the logistics industry. International Journal of Business and Economic Affairs, 4(5), 201-213. https://doi.org/10.24088/IJBEA-201945001

36. Shahzore (2002). Sample size and factor analysis. Psychological Methods, 4, 84-99. https://doi.org/10.1037/1082-989X.4.1.84

37. Sharaft. (2002). Electronic payments and attitudes of people about them. The First International Conference on Commerce, Tehran.

38. Thakur, M., Tveit, G. M., Vevle, G., \& Yurt, T. (2020). A framework for traceability of hides for improved supply chain coordination. Computers and Electronics in Agriculture, 174, 105478. https://doi.org/10.1016/j.compag.2020.105478

39. Tian, C., Zheng, H., \& Meng, F. (2018). The design and implementation of data collection middleware for logistics traceability. International Journal of Internet Manufacturing and Services, 5(2-3), 245-259. https://doi.org/10.1504/IJIMS.2018.091995

40. Tse, D. K., \& Wilton, P. C. (1988). Models of consumer satisfaction formation: An extension. Journal of Marketing Research, 25(2), 204-212. https://doi.org/10.1177/002224378802500209

41. Tzokas, N., \& Saren, M. (1997). Building relationship platforms in consumer markets: A value chain approach. Journal of Strategic Marketing, 5(2), 105-120. https://doi.org/10.1080/096525497346820

42. Verhoef, P. C., Franses, P. H., \& Hoekstra, J. C. (2002). The effect of relational constructs on customer referrals and number of services purchased from a multiservice provider: Does age of relationship matter? Journal of the Academy of Marketing Science, 30(3), 202-216. https://doi.org/10.1177/0092070302303002

43. Wangenheim, F. (2003). Situational characteristics as moderators of the satisfaction-loyalty link: an investigation in a business-to-business context. Journal of Consumer Satisfaction, Dissatisfaction and Complaining Behavior, 16, 145-156.

44. Waseem-Ul-Hameed, S. N., Azeem, M., Aljumah, A. I., \& Adeyemi, R. A. (2018). Determinants of e-logistic customer satisfaction: A mediating role of information and communication technology (ICT). International Journal of Supply Chain Management, 7(1), 105-111.

45. Zack. (2005). Impact of e-commerce in lowering operational costs and raising customer satisfaction. Journal of Manufacturing Technology Management, 17(3), pp.283-302. https://doi.org/10.1108/17410380610648263

46. Zeithaml, V. A., Bitner, M. J., \&Gremler, D. D. (2006). Service marketing: Integrating customer focus across the firm (4th ed.). New York, NY: McGraw-Hill/Irwin.

47. Zeithaml, V., \& Bitner, M. (2003). Service Marketing: Integrating Customer Focus across the Firm. New York, NY: McGraw-Hill.

48. Zeithaml, V., Berry, L., \& Parasuraman, A. (1996). The behavioural consequences of service quality. Journal of Marketing, 60(2), 31-46. https://doi.org/10.1177/002224299606000203 